\title{
Online Booking as A Marketing Strategy: A Survey on Hotels in Antalya
}

\author{
Assoc. Prof. Dr. Mustafa BOZ \\ Canakkale Onsekiz Mart University - Faculty of Tourism - Turkey
}

\begin{abstract}
The importance of new ICT technologies for the travel and tourism industry has increased enormously for the last twenty years. Internet, especially, the web applications has revolutionalised the industry. The internet became a new distribution channel as a marketing strategy for the travel and tourism industry. One of the most widespread applications is online booking for accomodation industry.

This paper consists of two main parts: In the first part, in the light of literature, the concept, tools, properties, development, pros and cons of online booking system for accommodation establishments were examined. In the second part of the paper, a survey was realised among 189 hotels in Antalya, where is accepted as the tourism capital of Turkey. A face to face interview method through a semi-structured questionnaire was used in the survey. In general, the reliability of the questionnaire was analyzed. And it was tried to determine traditional and online booking system applications of the hotels. In the statistical evaluation of the survey, descriptive statistics were used to analyse the results. In the final part of the paper, research findings were introduced, interpreted and recommendations were developed.
\end{abstract}

Keywords: Online Booking, Distribution Channels in Accomodation, Tourism Industry, Internet Applications, Hotels in Antalya

JEL Codes: M31, M37, O14, O33

\section{Introduction}

Over the past few years, the use of online booking system has increased globally and this trend is set to continue. With the internet more accessible and convenient than ever, consumers are opting to book accommodation online, a move that has seen a change in the way hotels get their rooms to market (Carter, 2013). Over the past two decades, industrial marketers have adopted increasingly complex channel strategies in response to shifts in consumer shopping behavior, the globalization of markets, and the advent of the internet (Webb, 2002:96). Business (B2B) and Business to Consumers (B2C) application has changed the situation rapidly (Buhalis and Licata, 2002:208). Unarguably, online tourism has successfully emerged as a platform that enables direct bookings, electronic payments, business to business (B2B) and business to consumer (B2C) trading among product marketers, accomodation establishments, travel agents, resellers and customers. Internet and related developments have been quite instrumental in growth of online tourism and online economy (Dixit et al. 2006).

\subsection{The Concept of Online Booking System}

\section{Related Literature}

An online booking /reservation system will let you accept bookings for your services online (Tani, 2012). Technology has transformed many aspects of life in the 21 st century, including the way many of us make reservations. Whether booking tickets for a show, a seat on an airplane or a room to spend the night, online booking systems make the process fast and easy (Blank 2014). Online tourism equips a tourist, tour operator or travel agent for convenient exchanges using electronic medium. User groups globally are finding online technologies supportive in decision making for availing tourism products and services (Dixit et al., 2006). Airlines, hotels, and tour operators, all of whom play an important role and have their own web sites, have been joined by 'travel gates'. These are websites or Internet portals, which allow a consumer to book a hotel either as a separate service or as part of a package. These travel gates are newcomers in the market and compete with existing offerors (Alleweldt et al., 2009:3).

\subsection{Multichannel Distribution Strategies}

President and CEO of Hospitality eBusiness Strategies (HeBS) Max Starkov (2011:25) emphasizes that "There is no doubt hotel distribution has changed dramatically since the advent of the internet. Online distribution, social media and the mobile web have all changed how we connect with, engage and ultimately convert customers. But the fundamental principles of hotel distribution have not changed that much". Firms benefit from multichannel distribution strategies in a variety of ways. First, it allows them to better adapt to changing customer needs and shopping patterns. Such adaptive capability has proven useful as they attempt to 
respond to novel distribution channels, including the internet. Second, companies with broad product lines can benefit because it is unlikely that a single channel type will be optimal for all products. Third, firms with excess manufacturing capacity can benefit from additional outlets when existing channels are saturated with supply. Finally, additional channels enable the supplier to focus on more precise target markets, thereby improving overall competitiveness (Webb and Didow, 1997 63-64; Webb, 2002:96).

While using such a complex distribution strategy offers many potential benefits to the supplier organization, it presents some managerial challenges as well. Multiple channels place competing demands on internal company resources such as capital, personnel, products, and technology. Moreover, the various distribution channels may compete with each other for the same customers in the marketplace, increasing the likelihood of intermediary dissatisfaction and customer confusion (Webb, 2002:96). Internet marketing firm Sabre Hospitality Solutions says "In a world of multi-channel marketing and distribution, hotels have multiple new revenue-building opportunities. But you must ensure your own direct channels remain the focus of your distribution strategy in order to succeed (Heller, 2011).

\subsection{Growth of Online Booking System}

Global online travel sales record healthy growth over the last decade, public access to and the use of online booking systems has increased globally (Agheorghiesei and Ineson, 2011:45). Dramatic shift to online distribution Voice and GDS travel agent, the traditional hotel reservation channels, have experienced consistent declines over the past 16 years. The ETRAK quarterly benchmarking report, which summarizes booking data from the top 30 hotel chains worldwide, illustrates well the significant shift from traditional to online channels (Starkov, 2011:26).

Some recent surveys show the growth of online booking system as below: (Bookeasy, 2014; Google/Compete Hotel Online/Offline Study, Nov 2010; Euromonitor International, 2014).

- Sixty per cent of travellers say they book online when the product is available.

- Booking online was the most dominant channel - Only 1 in 6 bookers indicated booking over the phone or in person.

- Global travel and tourism sales up from US $\$ 2,260$ billion (2013) to US\$2,840 billion (2017).

- Healthy growth driven by rising number of trips in advanced and emerging markets.

- Global online travel sales accounted for US\$590 billion (2013), 25\% of total sales.

- Online hotel sales in Western Europe reach 26\% of the market

- Online hotel sales are growing fast in Western Europe, catching up with air online sales

- Accounted for US\$36 billion in 2013,26\% of total hotel sales

- Expected to grow to US $\$ 60$ billion by 2017 , equally $40 \%$ of total hotel sales

- Strong growth for online hotel sales in Eastern Europe

- Online hotel sales growth is especially strong in Eastern Europe due to low penetration

- Amounted to US $\$ 2.2$ billion in 2013, $17 \%$ of total hotel sales

- Forecast to more than double to US $\$ 4.8$ billion by $2017,24 \%$ of total hotel sales

- Spain is main destination market for online hotel bookings. Spain was the largest European destination for online hotel sales, US\$6 billion (2013)

- Italy achieved the sharpest growth in 2013 (+26\%), followed by Spain (+24\%)

- 2013 Global Travel and Tourism Total and Online Travel Sales by category are as follow (Figure 1).

- Air transport leads online travel sales, followed by hotels

- Air online sales accounted for US\$360 billion - $46 \%$ of total air travel sales

- Travel accommodation amounted to US\$164 billion, with a $23 \%$ penetration rate

- Hotel online sales penetration expected to recover over the next five years

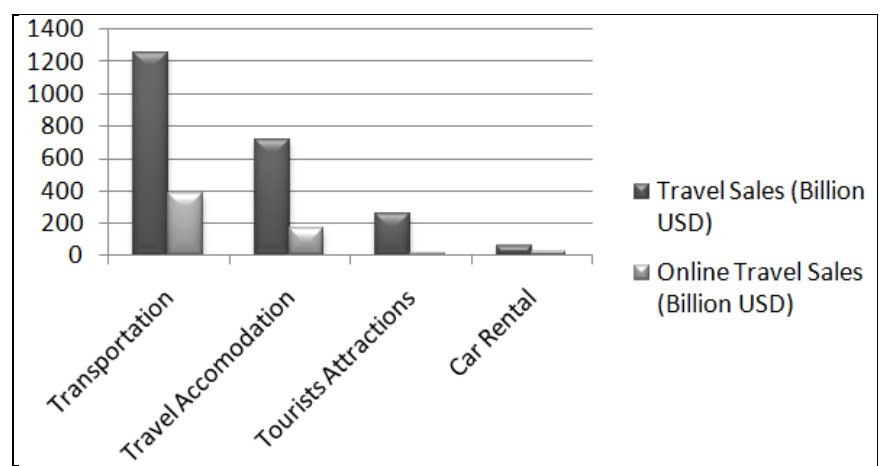

Figure 1: Global Travel and Tourism and Online Travel Sales by Category 2013 
Note: Includes both direct sales and sales through intermediaries

Source: Euromonitor International, 2014. The New Online Travel Consumer. Featuring Euromonitor International and the ETOA. 13 February 2014.

\subsection{Pros and Cons of Online Booking System}

The online booking system provides many advantages and some threats for consumers, intermediaries, and accomodation establishments. Accomodotion establishments have to find out the best system in order to sell products and services more efficiently using a combination of traditional and online channels. Online hotel reservation systems are increasing in importance and greatly facilitate crossborder consumer activity. The Internet has enabled hotels to contract directly with a huge number of potential customers. It has also revitalised the role of agents and lead to a new type of agent, the web agent or travel gate, selling a far wider range of accommodation on behalf of a far wider range of hotels. However, while online booking has increased the range of offers available, there are also some emerging worries due to examples of unfair commercial practices and lack of transparency related to such reservations (Alleweldt et al., 2009:1). Webb (2002:95) states that ecommerce presents business marketers with profound opportunities, including reduced costs, access to new market segments, and the ability to provide information worldwide on a continuous basis. However, ecommerce also introduces potentially significant challenges. Channel conflict is perhaps the most serious concern for companies as they add e-commerce.

\subsubsection{Pros - Advantages}

To survive in the present keenly competitive environment, hoteliers should cut down their distribution costs and adopt new marketing distribution channels. Room bookings through a hotel website are one of the best approaches to achieving both these goals (Wong and Law, 2005:312).

Advantages of online booking system for accomomdation establishments and customers can be classified as follow ((McCole, 2000; Schegg et al., 2002:73-74; Wong and Law, 2005:323; Dixit et al. 2006; Alleweldt et al., 2009:4; Agheorghiesei and Ineson, 2011:45; Bookeasy, 2014).

- Travel and tourism products are ideal for marketing on the internet because of their intangibility. Tourists have, for the long time, relied on limited information from holiday brochures and other literatures to evaluate tours and destinations. At the same time, it has greatly facilitated the promotion and distribution of tourism products and has potentially enabled tourism destinations and enterprises to compete on a level playing field. A hotel website enhances the convenience of booking a room, which will spur growth in hotel occupancy levels.

- Online reservations can be a valuable cost-saving strategy. This may be especially true for the small and medium-sized hospitality enterprises (SMEs) that lack a larger property's economies of scale. Hoteliers may also achieve a better profit margin from the savings incurred in intermediary and labour costs in the handling of reservations.

- Further, the cost of losing customers has been drastically reduced by better communications secured through Internet resulting in an increase in loyalty and better customers' relations. The capabilities mainly in the form of improved web interface, content delivery, user experience, $24 \times 7$ availability, multi-channel contact, and online support have resulted in the development of sound base for its adoption globally.

- Tourists enjoy the advantages of "self-service" comfort (they do not have to go to the tour operators as they can go on the websites at anytime and anywhere if they have access to a computer), the possibility to compare prices, make a reservation and receive confirmation (so that they feel they are in control of the situation), avoid the travel agency's commissions, and not feel "urged" to take a decision in front of the travel agent; they have enough time to consider and make their choices. Both partners - tour operators and tourists - may benefit from the friendly and communicative environment of virtual communities, "active supporters in the shadow" (as well as "destroyers) of tourism online as they reunite and update by web posts information, opinions, comments, experiences, useful and detailed pieces of advice from tourists and for tourists related to travelling or the offer and performance of tour operators.

- The Internet also helps consumers exploit more transparent pricing. Travelers increasingly use the Internet to book a room and circumvent traditional hierarchical distribution structures.

- The new market matured new types of agents, internet agents or travel gates, emerged. These are agents without shops who by harnessing the global reach of the internet are able to offer a global or regional choice of hotels to consumers. This is a far wider range than the one-hotel or onechain website can offer. These new Internet agents have rapidly proved themselves as indispensable to hotels and other service suppliers as traditional agents were in the past.

- Other major advantages of the new technology for the travel industry are greater flexibility, in particular with regard to price. Depending on demand prices can be adjusted on a daily or shorter basis (yield management). The internet also allows service suppliers to deliver much more detailed information about 
products than brochures or media advertisements. This carries the potential to greatly increase transactional transparency, a vital matter for consumers.

- An online booking system will make it quick and easy for customers to view, book and pay for your product. If you sign up to a distribution network, it will allow you to make your product bookable on multiple websites, meaning more exposure and more sales. Many users go to online travel websites to comparison shop. They then look at your website to find the same or a cheaper price. Online booking tools can get you more direct business.

- Travellers also benefit from all of the above.

\subsubsection{Cons - Disadvantages}

A general phenomenon, that has been observed recently due to the flow of information, products and services available online, is valid in the context of online hotel booking is consumer confusion (Matzler and Waiguny, 2005), caused by too much information, unclear information or undifferentiated information. They found that although consumer confusion impacted negatively on potential online bookers' desire to seek further information and their decision-making processes, it was only unclear information that stopped them from booking online (Agheorghiesei and Ineson, 2011:46).

Disadvantages of online booking system for accomomdation establishments and customers can be stated as follow (Vyas, 2010; Smith, 2014; Trails.com, 2014).

- Online booking can have its pitfalls. It may not always be the right choice, especially if you have special needs.

- Online booking rarely gives you the opportunity to speak with someone knowledgeable about the service you are booking. In some cases, you may find testimonials on a website, but you can never be sure if they are real testimonials or paid advertisements.

- Booking travel online frequently requires that you pay at least a deposit and many times requires that you pay the whole cost of your service up front. You put yourself at risk to have your credit card number stolen or even your whole identity by booking through an insecure website.

- Many online travel sites advertise low rates to attract your attention and then add fees and surcharges for a much less competitive deal.

- The bargain rates that make booking online appear so attractive often mean giving up flexibility in your dates of travel or other such constraints.

- Many Tour Operators' System will allow the customer to book online but do not offer real time confirmation.

- Accomodation establishments may not have physical evidence and service quality whatever they mentioned in their websites.

- Accomodation establishments or intermediaries such as online travel agencies may not be trustful and well orginazed. They may behave unethically towards customers.

- In many countries, there are no regulations and laws suitable to online trade, or they are not sufficient.

\subsection{What to do for a successful Online Booking System}

Max Starkov (2011:26) emphasizes that "Hoteliers need to focus on distribution channels that pass the litmus test; in other words, those that are cost-effective, generate the most bookings, protect rate parity and price integrity and reach the targeted customer segments". The main focus and priority for any hotelier should be to sell as much inventory via the most cost-effective distribution channels that can potentially generate the most bookings, while preserving rate parity and price erosion. It is important to understand how the interrelationship among these factors affects the intention to make a booking on a hotel website. Since internet usage has grown rapidly, it is vital to identify how potential customers perceive hotel websites, because such information may give an indication of how online hotel reservations can be increased and a hotel's profitability be improved. Therefore, the internet, as a sales channel, can reduce distribution costs in the form of commissions to intermediate agents. A study of customer perceptions of those factors that prompt them to make the decision to purchase online will unquestionably provide a beter understanding of their shopping behaviour and allow a hotel to build a successful web page (Wong and Law, 2005:314).

Starkov (2011:26) determines that since the beginning of the economic downturn in 2008, a number of very important developments occurred that profoundly changed hotel distribution and customer engagement in hospitality. These are:

The hyper-interactive consumer: Over the past several years, a new breed of hyper-interactive travel consumers who are today's main hotel customers has emerged. The advent of social media and the mobile web has accelerated the hyper-interactiveness of enternet users and travel consumers in general. 
Social Media: Engaging your customers via social marketing has become not only the norm, but is expected by past, current and future hotel guests.

Mobile Web: The mobile channel has become an important distribution channel worldwide. Hotel guests are already mobile-ready, and hoteliers have to respond adequately to this growing demand.

Channel Convergence: Today's hyperinteractive travel consumers are seeing marketing messages across a variety of channels. Now more than ever, there is a convergence of new and traditional digital formats, of interactive and offline marketing channels.

Multi-Channel Marketing: Hoteliers need to reach future and current customers at multiple points. Unleashing a promotional campaign simultaneously across all available marketing channels produces a compounded effect and far greater returns than each individual marketing format.

According to Google/Compete Hotel Online/Offline Study (2010) accomodation establishments must take considiration the following points.

Rising demand for real-time services:

- Always connected consumers expect to receive real-time services from travel companies.

- Companies need to provide personalised alerts and information.

- Customer service needs to be available 24/7 and easy to access via mobile devices.

- Consumers' use of multiple screens is sequential or simultaneous.

- Smartphones are generally the starting point to then move to PC, tablet or TV.

- Companies need to build flexible technological architecture to reach consumers on all screens.

\section{Methodology And Findings}

This survey was conducted on April and May 2013 among 189 hotels in Antalya, where is accepted as the tourism capital of Turkey. According to Antalya provincial directorate of culture and tourism datas number of hotels in Antalya were 868 in 2012. A face to face interview method through a semi-structured questionnaire was used in the survey.

In the first part of the survey diffent properties of hotels were investigated as seen on table 1 . The hotels are mostly 5 stars $(85,6 \%) .74 \%$ of the hotels has $101-365$ rooms.

$55,6 \%$ has 260 - 750 beds capacity. 20,6 has 900 and over bed capacity. 76,5\% of the hotels are in operation for $4-6$ years. It can be said that most of the hotels are new establishments. $92,9 \%$ of the hotels belongs to Turkish enterprises. $84,7 \%$ of the hotels belongs to a chain. It can be noticed that most of the hotels belong to Turkish enterprises and chain business.

Table 1: Properties of Hotels

\begin{tabular}{|c|c|c|c|}
\hline Description & Frequency & Percent $(\%)$ & Valid Percent (\%) \\
\hline \multicolumn{4}{|l|}{ Establishment type (N:189) } \\
\hline Five star hotel & 155 & 82,0 & 85,6 \\
\hline Three star hotel & 26 & 13,8 & 14,4 \\
\hline Missing System & 8 & 4,2 & \\
\hline \multicolumn{4}{|l|}{ Number of rooms (N:189) } \\
\hline $44-70$ & 22 & 11,6 & 11,6 \\
\hline $101-180$ & 83 & 43,9 & 43,9 \\
\hline $305-365$ & 57 & 30,2 & 30,2 \\
\hline $450-475$ & 20 & 10,6 & 10,6 \\
\hline $650-700$ & 7 & 3,7 & 3,7 \\
\hline \multicolumn{4}{|l|}{ Bed capacity (N:189) } \\
\hline $30-100$ & 13 & 6,9 & 6,9 \\
\hline $120-245$ & 32 & 16,9 & 16,9 \\
\hline $260-370$ & 50 & 26,5 & 26,5 \\
\hline $670-750$ & 55 & 29,1 & 29,1 \\
\hline $900-1000$ & 21 & 11,1 & 11,1 \\
\hline $1200-1400$ & 18 & 9,5 & 9,5 \\
\hline \multicolumn{4}{|c|}{ Operation years of the establishment $(\mathrm{N}: 189)$} \\
\hline Between $4-6$ years & 137 & 72,5 & 76,5 \\
\hline $7-9$ years & 30 & 15,9 & 16,8 \\
\hline More than 10 years & 12 & 6,3 & 6,7 \\
\hline Missing System & 10 & 5,3 & \\
\hline \multicolumn{4}{|l|}{ Ownership Status } \\
\hline 100\% domestic partnership & 170 & 89,9 & 92,9 \\
\hline $51 \%$ and over domestic partnership & 11 & 5,8 & 6,0 \\
\hline $51 \%$ and over foreign partners & 2 & 1,1 & 1,1 \\
\hline Missing System & 6 & 3,2 & \\
\hline \multicolumn{4}{|c|}{ Chain Business - Independent Business (N:189) } \\
\hline Chain Business & 160 & 84,7 & 84,7 \\
\hline Independent Business & 29 & 15,3 & 15,3 \\
\hline
\end{tabular}


Online Booking as A Marketing Strategy: A Survey on Hotels in Antalya

\begin{tabular}{|l|l|l|l|}
\hline Name of the chain business (N:160) & 7 & 4,4 & 4,4 \\
\hline Mirache & 54 & 33,8 & 33,8 \\
\hline IC Hotels & 84 & 52,5 & 52,5 \\
\hline Papillon Belvin & 4 & 2,5 & 2,5 \\
\hline Limsbona Dea Beach & 5 & 3,1 & 3,1 \\
\hline Intersport Hotel - Prince Group & 4 & 2,5 & 2,5 \\
\hline Maritim Club Alan Tur & 2 & 1,3 & 1,3 \\
\hline Ayscha Balvin & \multicolumn{4}{|l|}{} \\
\hline Length of time that the hotels operate & 1 &, 5 &, 6 \\
\hline Seasonal & 179 & 94,7 & 99,4 \\
\hline Year-around & 9 & 4,8 & \\
\hline Missing System & \multicolumn{3}{|l|}{} \\
\hline
\end{tabular}

In the second part of the survey, booking /reservation systems of hotels were tried to revealed. 87,3\% of hotels use online booking sytem (Table 2). But the share of online booking is low within total room sales. As seen on table 3 , the share of online booking is $10 \%$ in $75,5 \%$ of hotels and $15 \%$ in $17,9 \%$ of hotels.

Table 2: Online booking usage of hotels

\begin{tabular}{|l|l|l|l|}
\hline Description & Frequency & Percent (\%) & Valid Percent \\
\hline Yes & 165 & 87,3 & 89,2 \\
\hline No & 20 & 10,6 & 10,8 \\
\hline Missing System & 4 & 2,1 & \\
\hline Total & 189 & 100,0 & \\
\hline
\end{tabular}

Table 3: The share of online booking within total room sales.

\begin{tabular}{|l|l|l|l|}
\hline Description & Frequency & Percent $(\%)$ & Valid Percent \\
\hline $1 \%$ & 1 &, 5 &, 6 \\
\hline $10 \%$ & 118 & 62,4 & 75,6 \\
\hline $15 \%$ & 28 & 14,8 & 17,9 \\
\hline $20 \%$ & 9 & 4,8 & 5,8 \\
\hline Missing System & 33 & 17,5 & \\
\hline Total & 189 & 100,0 & \\
\hline
\end{tabular}

Tour operators/ travel agents sell about $85 \%$ - 90\% of hotel rooms in Antalya. The main reason for this, in Antalya and around most of the hotels are marketed by international tour operators. $85 \%$ of foreign tourists visiting Antalya preferred package tours, and $82 \%$ of them used the all-inclusive (Aksu et al, 2008). As seen on table 4 Odeon, TUI, ETS, Joly Tour, and Tez tour are the tour operators/ travel agents that hotels cooperate mostly.

Table 4: Tour operators /travel agents that hotels cooperate

\begin{tabular}{|l|l|l|l|l|l|l|}
\hline Travel Agency & \multicolumn{4}{|l|}{ First agency } & \multicolumn{3}{l|}{ Second agency } & \multicolumn{2}{l|}{ Third agency } \\
\hline & Frequ. & Valid Percent & Frequ. & Valid Percent & Frequ. & Valid Percent \\
\hline Odeon & 84 & 49,2 & 15 & 8,8 & 10 & 5,8 \\
\hline TUI & 11 & 6,4 & 121 & 70,8 & 6 & 3,6 \\
\hline ETS & 30 & 17,5 & 7 & 4,1 & 122 & 71,3 \\
\hline Joly Tour & 19 & 11,1 & & & 2 & 1,2 \\
\hline Didimtur & 9 & 5,3 & & & 11 & 6,4 \\
\hline Tez Tour & 18 & 10,5 & & & 3 & 1,8 \\
\hline Mil Tur & & & 16 & 9,4 & & \\
\hline Pegas & & & 10 & 5,7 & & \\
\hline Anex Tour & & & 2 & 1,2 & & \\
\hline Diana Travel & & & & & 11 & 6,4 \\
\hline Öger Tour & & & & & 4 & 2,3 \\
\hline Birce tour & & & & & 2 & 1,2 \\
\hline Total & 171 & 100,0 & 171 & 100,0 & 171 & 100,0 \\
\hline
\end{tabular}

Hotels in Antalya usually market their surplus capacities online through national online travel agencies to domestic tourists (Table 5).

Table 5: Online travel portals that hotels cooperate

\begin{tabular}{|l|l|l|l|l|l|l|}
\hline Online Travel Agency & \multicolumn{2}{l|}{ First Online Agency } & \multicolumn{3}{l|}{ Second Online Agency } & \multicolumn{2}{l|}{ Third Online Agency } \\
\hline & Freq. & Valid \% & Freq.ue & Valid \% & Freq. & Valid \% \\
\hline tatilsepeti.com & 115 & 71,4 & 1 &, 7 & 2 & 1,4 \\
\hline tatil.com & 1 &, 6 & 69 & 46,9 & 1 &, 7 \\
\hline tatilbudur.com & 2 & 1,2 & & & 68 & 46,9 \\
\hline etstour.com & 33 & 20,5 & 2 & 1,4 & 5 & 3,4 \\
\hline
\end{tabular}


Online Booking as A Marketing Strategy: A Survey on Hotels in Antalya

\begin{tabular}{|l|l|l|l|l|l|l|}
\hline touristica.com.tr & 4 & 2,5 & 1 &, 7 & 16 & 11,0 \\
\hline tatilofisi.com & 1 &, 6 & 20 & 13,6 & & \\
\hline tripadvisor.com & 2 & 1,2 & & & & \\
\hline booking.com & 1 &, 6 & & & & \\
\hline teztour.com.tr & 2 & 1,2 & & & & \\
\hline anitour.com.tr & - & & 17 & 11,6 & & \\
\hline gezintisitesi.com & - & & 15 & 10,2 & & \\
\hline heryerdentatil.com & - & & 2 & 1,4 & & \\
\hline holidaychek.com & - & & 1 &, 7 & 16 & 11,0 \\
\hline firsatsepeti.com.tr & - & & 16 & 10,9 & 1 &, 7 \\
\hline mavizincir.com & - & & 1 &, 7 & & \\
\hline anextur.com.tr & - & & 2 & 1,4 & & \\
\hline tatilburada.com & - & & & & 19 & 13,1 \\
\hline ssctur.com & - & - & & & 15 & 10,3 \\
\hline bircetour.com.tr & - & & & & 2 & 1,4 \\
\hline Total & 161 & 100,0 & 147 & 100,0 & 145 & 100,0 \\
\hline
\end{tabular}

\section{Conclusion And Recommentations}

With the rapid development of ICT techonologies, today online applications have become an integral part of the tourism industry. Online booking systems are one of the most widespread applications. Online booking offers many advantages to all parties such as suppliers, intermediaries, and customers. Online hotel sales in Western Europe reach 26\% of the market and 17\% in Western Europe. On the other side, in Antalya Turkey, online hotel reservations are around 10\%. Because hotel rooms in Antalya and around are mostly sold by international tour operators and travel agents to foreign tourists. It can be said that international tour operators dominate the market. Rest of the room capacities are mostly sold to domestic tourists by traditional and online domestic travel agencies and by themselves.

To be able to use online booking system more effectively and profitable, marketing and distribution system of accomodation establishments have to be changed. Accomodation establihments are required to get rid of from the guidance of international tour operators. They must be able to market their rooms with their own organisations. They must establish new distribution channels.

Note: This paper has been supported as part of the Scientific Research Projects of Canakkale Onsekiz Mart University (Project No: 2011/087).

\section{References}

[1] Agheorghiesei, Daniela Tatiana and Elizabeth Ineson (2011). The Impact Of Online Booking Systems On Customer Loyalty In Romania. Revista de Turism. Volume (Year): 11 (2011). Issue (Month): 11 (December). 46-55.

[2] Aksu, Akın et al. (2008). Antalya Yöresi Turist Profili Araştırması. Working Paper, Akdeniz University.

[3] Alleweldt, Frank, Klaus Tonner and Marc McDonald (2009). Study on Online Hotel Reservation Systems, European Parliment, Policy Department Economic and Scientific Policy. IP/A/IMCO/FWC/2006-058/LOT 4/C1/SC8. 2009-02-01.

[4] Blank, Chris (2014). Advantages of an Online Booking System. Retrieved from Techwalla website: http://www.ehow.com/about_5449736_advantages-online-booking-system.html (15.07.2014).

[5] Bookeasy (2014). Why Should I Offer Online Bookings? Retrieved from bebookearsy website: sales@bookeasy.com.au | bookeasy.com.au (10.06.2014).

[6] Carter, Brea (2013). Online Hotel Bookings on the Rise. Retrieved 08.08.2013 from Hospitality Magazine website: http://www.hospitalitymagazine.com.au/accommodation/ online-hotel-bookings-on-the-rise (15.07.2014).

[7] Dixit, Manoj, Rakesh Belwal and Gurmeet Singh (2006). Online tourism and travel (analyzing trends from marketing perspective). Skyline Business School Journal, 3 (1). pp. 89-99. ISSN 1998-3425.

[8] Euromonitor International (2014). The New Online Travel Consumer. Featuring Euromonitor International and the ETOA. 13 February 2014.

[9] Google/Compete Hotel Online/Offline Study, Nov 2010. Retrieved from Think with Google website: www.google.com/think/insights (04.07.2014).

[10] Heller, Lorraine (2011). How to Manage Hotel Distribution Channels Effectively. Retrieved 18.01.2011 from Big Hospitality website: http://www.bighospitality.co.uk /Business/How-to-manage-hotel-distribution-channels-effectively (15.07.2014).

[11] McCole, P. (2000, April). Hindsight, foresight, or a Website? Hospitality, 17-20. cited from Schegg, Roland et Al. (2002). Benchmarks Of Web Site Design and Marketing by Swiss Hotels. Information Technology \& Tourism. Vol. 5, 73-89.

[12] Matzler, Kurt and M. Waiguny (2005). "Consequences Of Customer Confusion in Online Hotel Booking", in ENTER conference. Innsbruck cited from Agheorghiesei, Daniela Tatiana and Elizabeth Ineson (2011).

[13] Schegg, Roland et al. (2002). Benchmarks Of Web Site Design and Marketing by Swiss Hotels. Information Technology \& Tourism. Vol. 5, 73-89.

[14] Smith, Kaukab Jhumra (2014). The Disadvantages of Online Booking. Retrieved June 25, 2014 from Ehow website: http://www.ehow.com/facts_4968346_disadvantages-online-booking.html (10.06.2014).

[15] Starkov, Max (2011). Book now! special report: distribution. Retrieved April 2011 from Hotels website: www.hotelsmag.com (04.07.2014).

[16] Tani, Christabelle (2012). What's an Online Reservation System and Do You Need It? Retrieved from Rezdy Tour Operator website: http://www.rezdy.com/blog/bid/141559/ What-s-an-Online-Reservation-System-and-Do-You-Need-It (15.07.2014).

[17] Trails.com (2014). The Disadvantages of Booking Online. Retrieved from Trails.com website: http://www.trails.com/facts_9851_disadvantages-booking-online.html\# ixzz39i746ctm (15.07.2014). 
[18] Vyas, Juhi (2010). Disadvantages of Booking Online on Travel Portals Retrieved 10.082010 from Ezine Articles website: http://ezinearticles.com/?Disadvantages-of-Booking-Online-on-Travel Portals\&id=4832401 (15.07.2014).

[19] Webb, Kevin L. and Nicholas M. Didow (1997). Understanding Hybrid Channel Conflict: A Conceptual Model and Propositions for Research. Journal of Business-to-Business Marketing. 4:1, 39-78.

[20] Webb, Kevin L. 2002). Managing Channels of Distribution in the Age of Electronic Commerce. Industrial Marketing Management. 31 (2002) 95- 102.

[21] Wong, James and Rob Law (2005). Analysing the Ntention to Purchase on Hotel Websites: A Study Of Travellers To Hong Kong Hospitality. Management 24 (2005) 311-329. 